\title{
Restoring Fiscal Equilibrium in the Canadian Federation: The Strides of the Harper Government
}

\section{Sarah Chisholm}

\section{Dalhousie University}

\begin{abstract}
The Canadian federation is by no means a fiscal equilibrium and this imbalance has been a growing area of weakness for decades. However, the Harper Conservatives have acknowledged Canada's fiscal imbalance and have placed it as a top priority for their government. Since 2006 Harper and his government have committed, and followed through with, several significant efforts towards fixing Canada's fiscal imbalance through measures included in both the 2006 and 2007 federal budget plans. No other government in decades has taken such measures and actions to meet this goal. The paper begins by describing how Canadian fiscal relations have evolved into what has been termed the fiscal imbalance. The paper then outlines the actions the Harper Conservatives have taken to properly address the imbalance since 2006; including both the vertical and horizontal fiscal imbalances and the corresponding changes to the CST, CHT, the Equalization Program and the TFF. Lastly, the paper discusses the fiscal imbalance in relation to municipal governments and Harper's initiatives in that area.
\end{abstract}


On January 12th, 2006 newly elected Prime Minister, Stephen Harper, wrote a letter to Premier Ralph Klein (also the chairman of the Council of the Federation) regarding Canada's fiscal imbalances. The letter stated: "Immediately upon being elected, my government will begin consultations with the provinces and municipal representatives with the intention to reach a long-term, comprehensive agreement, addressing both the vertical and horizontal imbalances."(1) In fact, in the Conservative 2006 federal platform that fueled their first successful election in thirteen years, the fiscal imbalance was given particular priority. "The Conservative Government will work with the provinces in order to achieve a long-term agreement which would address the issue of fiscal imbalance in a permanent fashion.”(2)

The Canadian federation is by no means in a fiscal equilibrium, however the Harper Conservatives have acknowledged Canada's fiscal imbalance and have placed it as a top priority for their government. No other government in decades has acknowledged the presence of the fiscal gap and implemented tangible steps to reduce it like Harper's Conservatives. The fiscal gaps present in the Canadian federation are well on their way to being significantly narrowed so long as Harper's initiatives are followed through. The Harper Conservatives have acknowledged Canada's fiscal imbalances, placed it as a priority for their government, instilled plans in Budget 2006 and 2007 to fill these gaps and have begun taking appropriate action towards those ends. If all goes accordingly, the Harper government will leave Canada with a legacy: rebalancing fiscal relations within our federation.

This paper will begin by briefly describing how Canadian fiscal relations have evolved into what has been termed the fiscal imbalance. This section will set the context and prove that there is, in fact, a fiscal imbalance within Canadian federation. The paper will then shift to describe the actions taken by the Harper Conservatives since 2006 regarding this imbalance. This will begin with the vertical fiscal imbalance, emphasizing the changes to the Canada Social Transfer and the Canada Health Transfer. Next the paper will outline Canada's horizontal fiscal imbalance, paying particular attention to Harper's new initiatives for the Equalization Program and the Territorial Formula Financing arrangement. Lastly, the paper will address the fiscal imbalance in relation to municipal governments and Harper's proceedings in that area.

\section{The History of Canada's Fiscal Arrangements}

The fiscal arrangements of the Canadian federation have undergone numerous changes in the 140 years of its existence. These constant changes and shifts in policy have been designed with the intention to accommodate the dynamic needs of this diverse state. A brief history of Canada's fiscal arrangements from Confederation to present is necessary to understand how the current fiscal imbalance has grown.

To begin, the BNA Act of 1867 established extremely clear divides as to taxing and expenditure responsibilities among the provincial and federal levels of government. This, also, included the federal government's ability to collect 'by any mode or system of 
taxation' whereas the provincial governments were limited to 'direct taxation.'(3) Forms of direct taxation grew into the most effective revenue-raising tool and, therefore, the federal government began to establish its authority in that field. Due to the high costs of both World Wars, the federal government took over the personal, income and inheritance taxes in 1941.(4) To compensate for this take-over, the federal government allocated special grants to the provinces - this set the stage for what would become the high level of entanglement between federal and provincial fiscal transfers.

In the three decades following the war, many social institutions were created with the funding becoming the prime focus of discussion and negotiation between the two levels of government. The federal government's interest and ability to fund social programs (an area of provincial jurisdiction) led to an era of competitive federalism in which the two levels competed for fiscal resources and debated jurisdictional rights. The federal spending power, cost-shared programs and the Equalization Program emerged during these three decades following the war. The Equalization Program, created in 1957, was a major federal program created to address the horizontal fiscal gaps within the Canadian federation. To this day, this program has been highly examined, debated and undergoes constant readjustments. The major issues of concern regarding the Equalization Program that are highly disputed to this day are: the list of revenues being equalized, the standard to which revenues are equalized and the treatment and inclusion of natural resource revenues.(5) The horizontal fiscal gaps have widened and narrowed over the years as a result of the ever-fluctuating equalization formula. The horizontal fiscal imbalances within the Canadian federation hinted at elements of centralization. During the 1960s and 1970s, however, topics such as Quebec nationalism, regionalism, province building, and the oil and energy crises led to the decentralization of Canadian federation.(6)

In 1976 the Established Programs Financing changed the landscape of federal-provincial fiscal arrangements. The EPF eliminated three shared-cost programs (Medicare, postsecondary education and hospital insurance) and replaced them with tax points and cash transfers. These cash transfers were per-capita based rather than the former shared-cost route - a shift that meant the funding was no longer based on the provinces' expenditures.(7) Inevitably, this hampered the ability of the provinces to adequately fund their responsibilities and led to the opening of the vertical fiscal gap. Subsequently during the 1980s, Canada was plagued with high inflation and increasing deficits that resulted in the federal government decreasing the growth rate or annual escalation rate of the provincial transfers.(8)

During the 1990s, Canada's increasing deficit and debt burdens led to major federal expenditure cuts - one of the largest being transfers to the provinces. For instance, the 1995 Budget blended the transfers for health, post secondary and social assistance into one program: the CHST, and then cut the total funding from $\$ 18.5$ billion to $\$ 12.5$ billion within two years.(9) This major cut placed yet another strain on the provinces and led to further widening of the vertical fiscal gap. 
This history of Canadian fiscal relationships leads us to the present era. From 1995-2006, the governing Liberals acknowledged the presence of the horizontal fiscal imbalance, but year after year refused to acknowledge the vertical fiscal imbalance claiming there is merely a fiscal 'pressure' on the provinces, but ultimately they have access to the same revenue bases as the federal government.(10) For the first time in history, a Canadian government, the Harper Conservatives, has acknowledged and addressed both of Canada's fiscal imbalances and has made it a top priority to close these gaps. Budget 2006 began to outline the direction the Canadian federal government would take to achieve fiscal equilibrium, and Budget 2007 has furthermore provided the detailed and precise steps to meet that end. Minister of Finance, Jim Flaherty, announced during his March 2007 Budget; "through this budget we are delivering an historic plan worth over \$39 billion in additional funding to restore fiscal balance in Canada.”(11) Budget 2007 has provided realistic action plans for restoring vertical and horizontal fiscal imbalances and addressing the issue of municipal fiscal relations.

\section{$\underline{\text { Restoring the Vertical Fiscal Imbalance }}$}

Canada's vertical fiscal imbalance has long been a topic of heavy debate within the federation. In a letter from the federal government to the Council of the Federation's Advisory Panel on Fiscal Equilibrium in 2005, the Liberals wrote:

The Government does believe in the existence of a fiscal imbalance between the federal and provincial governments in Canada. Both orders of government have access to all the major sources of tax revenues and have complete autonomy in setting their tax policies to address spending pressures related to their respective jurisdictions.(12)

In 2006 the Advisory Panel completed their report on the fiscal imbalance and found that the fiscal prospects of the provincial governments look unsatisfying for the next 20 years. The report stated that on average the provincial and territorial revenues would increase by 3.6 percent each year until 2024-2025, however this must be compared to the expected 4.7 percent growth in total program expenditures during the same period.(13) This is a vertical fiscal imbalance and will only serve to widen the gap if left untreated. The forecast deals mainly with expenditures provided in the Canada Social Transfer and the Canada Health Transfer. In their publication titled "Reconciling the Irreconcilable," the Advisory Panel on Fiscal Imbalance argued that when the federal government restored fiscal health (by cutting transfers and producing surplus budgets) in the late 1990s it did not return to the provinces what it had taken.(14) They continued by commenting that raising provincial taxes would not solve the problem, rather it would only lead to increases in Canada's horizontal fiscal imbalance.(15)

Harper's concept of open federalism has taken into consideration the Panel's report, arguments and recommendations. In the 2006 Conservative federal platform, Harper promised to "ensure that any new shared-cost program in areas of provincial/territorial responsibility have the consent of the majority of provinces to proceed, and that provinces should be given the right to opt out of the federal program with compensation, 
so long as the provinces offer a similar program with similar accountability structures.(16) The Harper government has addressed the vertical fiscal imbalance and has implemented many initiatives in their 2007 Budget to restore equilibrium.

The major themes of the Budget's solution to the vertical fiscal imbalance include placing transfers on a long-term principles-based footing to ensure the provinces elements of stability and predictability. Equally important, the Budget seeks to clarify the roles and responsibilities of each level of government so as to eliminate non-jurisdictional spending. The Harper government also plans to restore vertical fiscal equilibrium mainly by channeling money through the Canada Social Transfer and the Canada Health Transfer systems rather than direct spending.

The Canada Social Transfer includes funding for three main areas: post-secondary education, social assistance and childcare. Previously, this transfer system was stunted due to lack of financial weight and unequal per capita allocation to all Canadians.(17) In Budget 2007, the Harper government will add \$687 million to the transfer in 2007-2008 to ensure equal per-capita funding to all provinces. In addition, $\$ 800$ million more will be included in the CST in 2008-2009 to cover post-secondary initiatives. As well, $\$ 700$ million will be added to the CST's 2006-2007 level of $\$ 6.2$ billion for social programs. Finally, in Budget 2007 the Harper government has allocated \$5.6 billion in 2007-2008 alone to childcare, (this includes the new addition of $\$ 250$ million for 25000 new childcare spaces). Compare this with the Liberal Budget 2005 where the issue of childcare was touched upon only very briefly: " 5 billion over the next five years to start building a framework for an Early Learning and Child Care initiative in collaboration with provinces and territories.”(18) In Budget 2007, the childcare plan has a clear direction with numerous goals, numbers and detailed allocation paths that demonstrate the Conservative's commitment to ensuring effective national childcare. Overall, the CST base will be increased by $\$ 687$ million in 2007-2008, in 2009-2010 an addition $\$ 1.05$ billion will be added to that base and the 3 percent annual escalation rate will begin from there.(19) Moreover, the CST has been renewed until 2013-2014, placing it right alongside the Canada Health Transfer.

The changes made to the Canadian Health Transfer are another area of the 2007 Budget that is serving to narrow the vertical fiscal gap. In 2004 the Liberal government implemented the 10 Year Plan to Strengthen Health Care, an action plan to strengthen the Canadian health care system based on a number of principles decided at the First Ministers Meeting on the Future of Health Care 2004. The Harper Conservatives have shown support for this plan, which will allocate $\$ 41.3$ billion to the provinces and territories over 10 years in an equal per-capita fashion.(20) What's more is the annual escalator rate of 6 percent of the $\$ 19$ billion base that began in 2006-2007. The Advisory Panel reported in 2006 that this escalator would be sufficient as it is in line with the growth rate of expenditures predicted until 2024-2025.(21) The 10 Year Plan expires in 2014-2015 and, therefore, the government will wait until then to implement its equal percapita cash allocation of the CHT. 
In the Advisory Panel's 2006 report on the vertical fiscal imbalance, a few major conclusions were drawn, based upon data that made educated predictions until the years 2024-2025. To begin, they predicted that the federal governments would be in a much more favorable stance than the provincial governments in terms of fiscal positions. Secondly, using the aforementioned position they decided it was within reach for the federal government to make solid, long-term commitments to restoring the vertical fiscal imbalance - this was an attainable possibility. Thirdly, they concluded that the provinces are extremely dependent on their ability to contain health and education costs to a minimum because even though both governments have access to similarly increasing revenues, the expenditures of the provinces and territories are presumed to grow at a much faster rate.(22)

Fortunately, Harper has taken these forecasts into consideration when his government drew their 2007 Budget. Public policy expert France St. Hilaire claims that since 1997 the federal government has preferred direct spending in areas of provincial jurisdiction, causing serious strain on the provincial governments.(23) Changes to the Canada Social Transfer and Canada Health Transfer have been designed with heavy emphasis on relieving this strain and closing the fiscal gap between the federal and provincial governments. Harper's Conservatives have drawn an attainable route to achieving vertical fiscal equilibrium; it is now in the hands of the current government and the successive governments to follow through.

\section{$\underline{\text { Rebalancing Horizontal Fiscal Arrangements }}$}

Due to Canada's vast geography, diverse population and wide range of social conditions, no two provinces are alike. These factors lead to multiple differences in economics and politics. All provinces vary in population, revenue-raising abilities, resources, personal initiatives and self-interests. There is no denying the fact that horizontal fiscal imbalances are prevalent and very present in the Canadian federation. The Harper Conservatives successfully installed action plans in their 2007 Budget to address and reform this issue. Their main focuses lie with the Equalization Program and the Territorial Financing Funding arrangement. The new initiatives within these two programs focus toward bringing them back to principle-based formulas that will ensure stability and predictability. Combined efforts will include $\$ 2.062$ billion more over the next two years than the previous system.(24) Harper's Conservatives have taken the issue of horizontal fiscal imbalances seriously, as it has been a looming and highly debated issue in the Canadian federation for decades. His government has placed a firm commitment on this topic and has outlined their actions to ensure equilibrium in the near future.

The Equalization Program was created in 1957 and has since undergone countless adjustments to better meet the dynamic needs of Canada's diverse provinces. Notably in 2004/2005, under the Liberal government, the formula based calculations to measure provincial entitlements were suspended and replaced with an interim formula. The interim formula was unpopular as it used a fixed pool with a fixed escalator rather than a dynamic pool based on measurements of fiscal capacity. In the Advisory Panel's review 
of the horizontal fiscal imbalance they found that this interim formula "abandons a key feature of Canada's Equalization Program - namely, the principle that equalization payments to a province are to be determined by its fiscal capacity relative to that of a standard."(25) This formula did not address the fiscal varieties of the provinces, however the Harper government has made many adjustments to meet those ends.

The Harper Conservative's 2007 Budget included many of the recommendations set forth in the O'Brien Report of 2006. Most importantly, this includes a shift to a ten-province standard (rather than a five-province standard) in order to heighten the national Equalization standard and ensure less wealthy provinces are brought up to a national average. Next includes adjustments to the highly contested inclusion of natural resource revenues: 50 percent exclusion from the Equalization formula to ensure that resourceproducing provinces gain some economic benefits from these revenues. In addition, Harper has implemented a fiscal capacity cap to make sure "have-not" provinces do not gain higher fiscal capacity than the "haves." Lastly a "smooth transition" has been included in the 2007 Budget so as to guarantee stability and predictability. This transition will make sure receiving provinces obtain no less than the 2007-2008 payments in the coming years.(26) In accordance with the new Equalization program, the province's CST and CHT transfers would also not drop below 2007-2008 levels.

The adjustments made to the Equalization Program in the Harper government's Budget were designed to restore the fiscal imbalance among the provinces. The current government has made significant efforts and has consulted numerous review panels and reports (Advisory Panel, O’Brien Report) in order to implement the most beneficial program for all Canadians. In Paul Boothe's essay "The Stabilization Properties of Canada's Equalization Program", he points out "provincial and territorial ministers have been urging the removal of the Equalization ceiling and for a return to a ten-province standard rather than the current five-province standard."(27) The Conservative government has taken into consideration the desires of the provinces and is working with them in order to ensure a highly advantageous program for as many provinces as possible.

The Territorial Formula Financing (TFF) arrangement is another program that has undergone changes in the recent budget. Similar to the Equalization Program, in 2004 the TFF also had its formula-based calculations suspended. The 2007 Budget, however, reinstalls these principle-based formulas in order to meet the needs of Canada's three territories. The Harper government consulted the territories and came up with a fully endorsed set of guidelines for the new TFF. To start, the formula-based approach would return with additional 'gap-filling' grants to recognize the differences among the three territories. For instance, Nunavut is much less developed in areas of healthcare, education and social well-being than the other territories.(28) Next, there would be a new and easy approach to how resources are incorporated in territorial revenue measurements. In addition, the government will provide the territories with new incentives in order to increase revenue and economic growth so that eventually they can become self-reliant and self-sufficient. Budget 2007, also, sets out a simple transfer and estimate system so 
that the territories can count on the stability and predictability of the federal government. Lastly the government will treat resource revenues in a similar fashion as the provinces: 50 percent exclusion from transfer payment calculations. Overall, in 2007-2008 the federal government will allocate $\$ 2.2$ billion to the three territories - \$115 million more than the previous year.(29)

Every year Canada's provinces and territories increase their expenditures in response to growing populations and costs of providing adequate and comparable services. Combine this burden with the inability of some provinces and territories to raise sufficient funds to meet their own needs, while others have no problems at all. This incongruence has lead to an undeniable horizontal fiscal imbalance. The Harper government recognizes this imbalance and the increasing strain on provincial and territorial governments to fund programs with the similar ease as of their counterparts. In the 2007 Budget the Conservatives laid a solid framework to restore the gap and ensure that all provinces and territories can offer comparable services at comparable tax rates.(30) The Harper government has a clear and attainable guideline as to how to achieve fiscal equilibrium among the provinces. In similar fashion to the vertical fiscal imbalance, the framework and instructions are there, it is now up to the current and future governments to uphold and adhere to these guidelines.

\section{$\underline{\text { The Fiscal Imbalance and Municipalities }}$}

Little is known or documented regarding the fiscal imbalance in relation to municipal politics. Municipalities are simply 'creatures of the provinces,' meaning they are under provincial jurisdiction and have no official relationship to the federal government.(31) During the 1996-2001 period, provincial and federal governments have produced an average of 25 percent increase in revenues; compare this to the 14 percent increase that municipalities have simultaneously incurred.(32) Municipalities, like provinces, are currently experiencing annual expenditure increases while simultaneously lacking efficient growth of their revenue-raising capabilities.(33) Essentially municipalities suffer in the same manner as provinces do in regards to a vertical fiscal imbalance.

There are three major areas of concern for municipalities and their fiscal relationships. Primarily the "offloading" of certain federal and provincial services onto their backs has caused an increase to their annual expenses. While their responsibilities increase, however, their revenues- raising abilities do not. Secondly, the provinces and the federal government have chosen to decrease their responsibilities in certain areas, while they have not specifically transferred the role to another level of government, the municipalities feel the need to fill this hole.(34) Thirdly, both the federal and the provincial governments often set standards or requirements for the municipalities to fulfill (such as sewage, water testing, etc) but do no provide any compensation or funding for these new initiatives. This is often referred to as "unfunded mandates."

Enid Slack points out in her article, "Fiscal Imbalance: The Case for Cities" that municipalities appear to be quite healthy due to the restrictions placed on them via 
provincial legislation: the inability to run deficit budgets, caps on borrowing, and somewhat inflexible tax-increase options.(35) Slack notes that the watchful-eye of the provinces on municipal affairs contributes to their seemingly balanced budgets.(36) She, also, argues that even though they appear to be healthy on paper, real evidence of weakness is seen in the sacrifices they make to service provisions and infrastructure. The effects of weak municipal fiscal autonomy and low financial profiles place municipalities in competition with one another and can seriously deter residents and potential commercial investors - an effect detrimental to the Canadian economy as a whole.

The Harper Government has acknowledged the fiscal strains on municipal governments. At the Federation of Canadian Municipalities Conference in 2006, Harper gave a speech in which he stated that the fiscal imbalance is

"Not just about federal-provincial relations. Ultimately it is about the relationships of all levels of government with our citizens. And municipalities - represented most broadly by your federation - are a vital partner in this dialogue. In the meantime we'll do our part. By urging the provinces to meet their obligations to municipalities and by containing dialogue with both levels of government.”(37)

In the 2007 Budget, the Harper Conservatives outlined a few initiatives to address municipal concerns. First off, municipalities are included in the $\$ 5$ billion per year increase by 2009-2010 for infrastructure support. This allocation is eight times greater than the funding recorded during the 1994-1995 to 2004-2005 era.(38) In addition, this funding will be extended until 2014-2015. The government, also, has committed to extend to Gas Tax Fund for municipalities transfer from 2010-2011 until 2014-2015. Two billion per year will be transferred under this program for an additional \$8 billion.(39) Lastly, the government will continue to honor the very important 100 percent GST rebate for municipalities - this will continue to provide reliable, stable and predictable financial funding.

The Harper Conservative's have responded to the municipal outcry for more public funding in their 2006 and 2007 budgets, which allocate more money and concentration on ensuring dialogue and co-operations among all levels of government. Likewise, by providing strong foundations and actions to rebalance the vertical and horizontal fiscal relations in the federation, ultimately this should lead to increases in municipal funding. If provinces begin to ease up on their limitations to municipalities due to their own internal fiscal relaxation, this should lead to better provincial-municipal fund sharing. Municipalities have a long way to go to ensure their financial needs are met, and this issue will gain increasing precedence in the Canadian federation as urban sprawl and municipal autonomy movements continue to grow. The Harper government has taken adequate steps to tackle this issue in the past two Budgets, and has committed to increasing dialogue and co-operation among all levels of government, promoting ideals in their policy of open federalism that will surely benefit the municipalities in years to come. 


\section{$\underline{\text { Conclusion }}$}

The fiscal imbalances present in the Canadian federation have been a growing area of weakness for far too long. In 2006 with the election of the Harper Conservatives, this trend has begun to change. Harper has firmly stated; "the fiscal imbalance impacts almost all Canadian provinces, territories and municipalities and is a threat to the proper functioning of the Canadian federation."(40) Furthermore, since winning their election in 2006 the Conservative government has made restoring fiscal equilibrium in Canada a top priority. Both the 2006 and 2007 Budget have included tangible, realistic and favorable action plans to work towards both vertical and horizontal fiscal equality and strengthening fiscal relations with Canada's municipalities. The Advisory Panel on the Fiscal Imbalance predicts the federal government's financial position to be quite strong in the upcoming years. They have hypothesized the federal budget surplus to increase from $\$ 10.5$ billion in 2005-2006 to $\$ 23.7$ billion in 2024-2025.(41) The Canadian federal government has the resources and ability to commit itself to long-term, predicable and stable goals to restore fiscal equilibrium in the Canadian federation. The Harper government has taken monumental steps, unlike any other government, in acknowledging

and addressing fiscal imbalances and promoting the ideal of closing these gaps. The framework, guidelines and road-map to fiscal equilibrium have been incorporated in the 2006 and 2007 federal Budgets - it is now up to the current and successive governments of Canada to continue to ensure these mandates are met.

\section{Biography}

This is Sarah Chisholm's first publication and she will be graduating from Dalhousie University with combined honors Bachelor Degree in Political Science and Canadian Studies in the spring of 2010. Sarah is passionate about Canadian politics and is specifically interested in French-English relations, regionalism and fiscal politics. Sarah has recently represented her school at the 2008 World Model United Nations Conference in Puebla, Mexico where she took on the role of Romania on the United Nations Environmental Program. 
Footnotes

(1) As sited in: Canada, Advisory Panel on the Fiscal Imbalance, Reconciling the Irreconcilable: Addressing Canadas Fiscal Imbalance. (Ottawa, Council of the Federation, 2006) 11.

(2) Stand Up For Canada: Conservative Party of Canada Federal Election Platform 2006 (Conservative Party of Canada, 2006.

(3) As sited in: Reconciling the Irreconcilable, 22.

(4) Reconciling the Irreconcilable, 22.

(5) Reconciling the Irreconcilable, 26.

(6) Kristin Good, Intergovernmental Relations, 9 October 2007, slide 17.

(7) Odette Madore, Federal Support for Health Care Under Bill C-28. Parliamentary Research Branch. 21 November 2003 http://dsp-psd.pwgsc.gc.ca/CollectionR/LoPBdP/PRB-e/PRB0320-e.pdf

(8) Reconciling the Irreconcilable, 25.

(9) Reconciling the Irreconcilable, 25.

(10) Kristin Good, Fiscal Federalism, 16 October 2007, slide 28.

(11) Canada, Department of Finance, Aspire to a Stronger, Safer, Better Canada The Budget Speech 2007 (Ottawa: Minister of Finance, 19 March 2007) 5.

(12) Reconciling the Irreconcilable, 107.

(13) Reconciling the Irreconcilable, 64.

(14) Reconciling the Irreconcilable, 67.

(15) Reconciling the Irreconcilable, 67.

(16) Stand Up For Canada, 43

(17) Canada, Department of Finance, Restoring Fiscal Balance for a Stronger Federation: Aspire to a Stronger, Safer, Better Canada (Ottawa: Department of Finance, 2007) 21.

(18) Canada, Department of Finance, The Budget Plan 2005 (Ottawa: Department of Finance) 15. 
(19) Restoring Fiscal Balance for a Stronger Federation, 29.

(20) Canada, Department of Finance, The Budget Plan 2007 (Ottawa: Department of Finance, 2007) 93.

(21) The Budget Plan 2007, 75

(22) Reconciling the Irreconcilable: Addressing Canadas Fiscal Imbalance, 67

(23) France St. Hilaire, Écarts et Déséquilibres Fiscaux: La Nouvelle Donne du Fédéralisme Canadien Institute for Research on Public Policy 2005, 27

(24) Restoring Fiscal Balance for a Stronger Federation, 4.

(25) Reconciling the Irreconcilable, 79.

(26) Restoring Fiscal Balance for a Stronger Federation, 16.

(27) Reconciling the Irreconcilable, 175.

(28) Restoring Fiscal Balance for a Stronger Federation, 19.

(29) Restoring Fiscal Balance for a Stronger Federation, 19.

(30) Restoring Fiscal Balance for a Stronger Federation, 4.

(31) Kristin Good, Creatures of Federalism, 20 November 2007, slide 3.

(32) Our Cities, Our Future: Addressing the Fiscal Imbalance in Canadas Cities Today. Big City Mayors Caucus 2006, 2006, retrieved from: http://www.fcm.ca/english/documents/bcmcfinal.pdf

(33) Enid Slack, Fiscal Imbalance: The Case for Cities. Institute on Municipal Finance and Governance Munk Center for International Studies, University of Toronto, 2003: 3.

(34) Our Cities, Our Future, 3.

(35) Our Cities, Our Future, 7.

(36) Our Cities, Our Future, 9

(37) Building Prosperity Together, Federation of Canadian Municipalities. 2006: 10.

(38) Restoring Fiscal Balance for a Stronger Federation, 34. 
Federalism-e: Volume 9

(39) Restoring Fiscal Balance for a Stronger Federation, 37.

(40) Our Cities, Our Future, 5.

(41) Reconciling the Irreconcilable, 62. 


\section{References}

Advisory Panel on the Fiscal Imbalance. (2006). Reconciling the irreconcilable: Addressing Canada's fiscal imbalance. Ottawa: Council of the Federation.

Budget will target fiscal imbalance: Flaherty. (2007, March 18). Retrieved from CBC News Archives http://www.cbc.ca/canada/story/2007/03/18/flaherty.html?ref=rss

“Building Prosperity Together.” (2006). Federation of Canadian Municipalities. Retrieved from http://www.fcm.ca/english/publications/cover5.pdf

Conservative Party Of Canada. (2006). Stand up for Canada: Conservative Party of Canada federal election platform 2006. Ottawa: Conservative Party Of Canada.

Department of Finance Canada. (2005). The budget plan 2005. Ottawa: Government of Canada.

Department of Finance Canada. (2007). Aspire: The budget plan 2007. Ottawa: Government of Canada.

Department of Finance Canada. (2007) Federal transfers to the provinces and territories: 10 year plan to strengthen health care. Ottawa: Government of Canada. Retrieved from http://www.fin.gc.ca/FEDPROV/typhc_e.html

Department of Finance Canada. (2007). Federal transfers to the provinces and territories: CST. Ottawa: Government of Canada. Retrieved from http://www.fin.gc.ca/FEDPROV/cste.html

Department of Finance Canada. (2006). A brief history of the fiscal relations debate in Canada.

Retrieved from http://www.fin.gc.ca/budget06/fp/fpa1e.htm

Good, K. (9 October 2007). Intergovernmental Relations. Slide 17.

Good, K. (16 October 2007). Fiscal Federalism. Slide 28.

Good, K. (20 November 2007). Creatures of Federalism. Slide 3.

Government of Canada. (2007). Restoring Fiscal Balance For A Stronger Federation: Aspire to a Stronger, Safer, Better Canada. March 19. Department of Finance. http://www.budget.gc.ca/2007/pdf/bkfbsfe.pdf

Harper, Stephen. (2006, April 20). Prime minister Harper outlines his government's priorities and open federalism approach. Speech in Montreal, Quebec. 
Health Canada. (2007). A 10-year plan to strengthen health care. Retrieved from http://www.hc-sc.gc.ca/hcs-sss/delivery-prestation/fptcollab/2004-fmm-rpm/index_e.html

Lazar, Harvey. Ed. 2005. Canadian Fiscal Arrangements: What works, what might work better. Montreal \& Kingston: McGill-Queen’s University Press.

Madore, Odette.(2003, November 21). Federal support for health care under Bill C-28. Parliamentary Research Branch. http://dsp-psd.pwgsc.gc.ca/Collection-R/LoPBdP/PRBe/PRB0320-e.pdf

Office of the Prime Minister (2006). Prime minister promotes open federalism. Retrieved from http://pm.gc.ca/eng/media.asp?id=1123

Our cities, our future: Addressing the fiscal imbalance in Canada's cities today. (2006). Big City Mayors' Caucus 2006. Retrieved from http://www.fcm.ca/english/documents/bcmcfinal.pdf

Slack, Enid. (2006). Fiscal imbalance: The case for cities. (Institute on Municipal Finance and Governance. Munk Center for International Studies. University of Toronto).

St. Hilaire, F. (2005). Écarts et déséquilibres fiscaux: La nouvelle donne du fédéralisme canadien. Institute for Research on Public Policy. Retrieved from http://www.irpp.org/po/archive/oct05/sthilaire.pdf 